\title{
PERSELISIHAN HUBUNGAN INDUSTRIAL PADA HARI BURUH NASIONAL
}

\author{
1Yusmedi Yusuf \\ 1 Universitas Islam Syekh-Yusuf \\ Email:yusmedi@unis.ac.id
}

\begin{abstract}
Abstrak
Perselisihan hubungan industrial yang terjadi setiap hari buruh nasional tanggal 1Mei setiap tahun, selalu diperingati oleh pekerja Indonesia dengan aksi mogok kerja dan unjuk rasa pada pemerintah. Padahal hukum ketenagakerjaan secara normative sudah mengatur hubungan industrial melalui Undang-Undang Nomor 13 Tahun 2003 Tentang Ketenagakerjaan jo Undang-Undang Nomor 2 Tahun 2004 Tentang Penyelesaian Perselisihan hubungan Industrial. Tuntutan kaum pekerja sudah berlangsung setiap tahun yang menyangkut materi upah minimum, pekerja kontrak (outsourching), pemutusan hubungan kerja sepihak dan sarana industrial lainnya. Pemerintah sebagai organisasi kekuasaan negara tidak berpihak kepada pekerja yang secara social ekonomi sangat lemah dalam memperjuangkan kesejahteraan hidupnya.
\end{abstract}

Kata Kunci: Perselisihan, Hubungan industrial, Hari Buruh Nasional. 


\section{A. PENDAHULUAN}

Perkembangan ketenagakerjaan di Indonesia tidak terlepas dari pengaruh hubungan industrial antara pemerintah, pengusaha dan serikat pekerja.Hubungan tripartite tersebut diperlukan dalam perlindungan terhadap pekerja pada setiap perusahaan.Peraturan hukum ketenagakerjaan dalam peraturan perundang-undangan,perjanjian kerja dan kesepakatan kerja bersama merupakan rambu hukum yang terus mengalami dinamika dalam hubungan industrial.

Beberapa permasalahan ketenagakerjaan di Indonesia selalu dimunculkan lewat aksi mogok kerja dan unjuk rasa kaum pekerja setiap tanggal 1 Mei pada hari buruh nasional.Pekerja dan serikat pekerja mengajukan tuntutan kepada pihak perusahaan dan pemerintah tentang aspek normative terhadap pekerja dalam persoalan upah minimum,sistem kerja outsourching atau pekerja kontrak,dan pemutusan hubungan kerja.

Perselisihan hubungan industrial memerlukan aspek penegakan hukum melalui peraturan Undang-Undang nomor 13 tahun 2003 tentang ketenagakerjaan dan Undang-Undang nomor 2 Tahun 2004 tentang perselihan hubungan industrial. Dalam imlementasinya ke dua peraturan perundangan tersebut belum menyentuh pada pihak yang berselisih, sehingga penyelesaian masalah sering dilakukan dengan aksi mogok kerja dan unjuk rasa kaum pekerja terhadap pihak pengusaha maupun pihak pemerintah.

Perselisihan hubungan industrial yang terjadi merupakan perbedaan pendapat yang mengakibatkan pertentangan antara pengusaha atau gabungan pengusaha dengan pekerja atau serikat pekerja karena adanya perselisihan mengenai hak dan kepentingan dan perselisihan pemutusan hubungan kerja serta perselisihan antara serikat pekerja dalam satu perusahaan". Pada bagian menimbang angka (b) Undang-Undang Nomor 2 Tahun 2004 tentang penyelesaian perselisihan hubungan industrial menyatakan: "Dalam era industrialisasi masalah perselisihan hubungan industrial menjadi semakin meningkat dan komplek, sehingga diperlukan institusi dan mekanisme penyelesaian perselisihan hubungan industrial yang cepat, tepat, adil dan murah."

Kebijakan pemerintah di bidang ketenagakerjaan sebagaimana dituangkan dalam Undang-Undang Nomor 13 Tahun 2003, perlu ada kajian secara lebih mendalam sebagai efektivitas hukum ketenagakerjaan sudah tidak dapat menyelesaikan kasus-kasus yang timbul dalam hubungan industrial. Padahal pemerintah cq.Dinas tenaga kerja Kota Tangerang mempunyai kewenangan terhadap aspek perlindungan pekerja sebagaimana disebutkan dalam bagian menimbang angka (b): "Bahwa 
dalam pelaksanaan pembangunan nasional tenaga kerja mempunyai peranan dan kedudukan yang sangat penting sebagai pelaku dalam tujuan pembangunan." Selanjutnya dalam bagian menimbang angka (c): "sesuai peranan dan kedudukan tenaga kerja diperlukan pembangunan ketenagakerjaan untuk meningkatkan kualitas dan peran sertanya dalam pembangunan ketenagakerjaan serta perlindungan tenaga kerja dan keluarganya sesuai dengan harkat dan martabat kemanusiaan."

Melihat aspek yuridis penyelesaian perselisihan hubungan industrial di atas, sudah selayaknya Undang-Undang ketenagakerjaan nomor 13 Tahun 2003 dijadikan pedoman bagi adanya mogok kerja dan unjuk rasa oleh serikat pekerja terhadap pengusaha tidak dilakukan kembali.

Berdasarkan permasalahan diatas, maka perselisihan hubungan industrial dapat diidentifikasi sebagai berikut:

Penyelesaian perselisihan hubungan industrial antara pihak pekerja, pengusaha dan pemerintah Kota Tangerang belum dilaksanakan berdasarkan Undang-Undang Nomor 2 Tahun 2004. Secara implementasi peran pemerintah, pengusaha dan serikat pekerja yaitu:

1. Peran pemerintah dalam meredam aksi demo pekerja/serikat pekerja

2. Peran pengusaha dalam penyelesaian Bipartite

\section{B. PEMBAHASAN}

Pasal 1 angka 16 Undang-Undang nomor 13 tahun 2013 menyatakan bahwa hubungan industrial adalah suatu sistem hubungan yang terbentuk antara pelaku dalam proses barang atau jasa yang terdiri dari unsur pengusaha,pemerintah dan pekerja didasarkan pada nilai nilai Pancasila dan Undang-Undang Dasar 1945.

Pelaksana hubungan industial ini harus senantiasa dijiwai oleh nilai ketuhanan, kemanusiaan, persatuan, kerakyatan dan keadilan.

Adapun tujuan hubungan industial adalah mengemban cita-cita proklamasi kemerdekaan Indonesia 17 Agustus 1945 dalam pembangunan nasioanal dalam mewujudkan masyarakat adil dan makmur serta ikut melaksanakan keadilan sosial melalui penciptaaan ketenangan bekerja,dan ketertiban untuk meningkatkan produksi dan kesejahteraan pekerja dalam persaingan pasar global.

Untuk melaksanakan hal tersebut di atas, maka perlu mewujudkan falsafah hubungan industrial yang kondusif dalam lingkungan kerja sebagai berikut: 
1. Lembaga Bipartite sebagai sarana hubungan industrial antara pengusaha dengan serikat pekerja dalam perusahaan.

2. Lembaga Tripartite sebagai sarana hubungan industrial antara pemerintah, pengusaha dengan pekerja atau serikat pekerja.

3. Perjanjian kerja sebagai sarana peraturan bersifat perdata dalam hubungan kerja.

4. Peraturan perusahaan sebagai sarana pendukung dalam produktivitas kerja dan efisiensi perusahaan.

5. Kesepakatan kerja bersama sebagai sarana peraturan antara organisasi serikat pekerja dengan perusahaan.

1. Penyelesaian persilisiahan hubungan industrial secara bipartite antara pihak perusahan dengan pihak seringkat pekerjaan, dalam implementasinya banyak penyelesaian masalah perundingan yang diadakan dalam perusahaan lebih banyak meneemui kegagalan dalam bergainning. Dalam perundingan anggota serikat pekerjaan kuat memahami permasalahan dan tutunan secara normative tentang kondisi ketenagakerjaan dengan kondisi manangemen perusahaan. Persilisihan hubungan industrial antara pihak pengusaha dengan pihak serikat pekerja dalam perusahaan. Terdiri pihak dari 2(dua) bagian :

1. Perselisihan hak yaitu perselisihan yang timbul karena salah satu pihak tidak memenuhi isi perjanjian kerja, peraturan perusahaan dana kesepakatan kerja Bersama antara serikat pekerja dengan perusahaan.

2. Perselisiahan kepentingan yaitu perselisihan yang terjadi akibat adanya perusahan syarat-syarat kerja atau yang timbul karena tidak adanya persesuaian paham antara serikat pekerja dengan perusahaan.

Pasal 1 ayat (2) undang-undang nomor 2 tahun 2004 menyatakan:

"Perselisihan hak adalah sebagai perselisihan yang timbul dengan tidak dipenuhinya hak, akibat adanya perbedaan pelaksanaan dan penafsiran terhadap perjanjian kerja, peraturan perusahaan dan kesepakatan kerja Bersama" 14

Sedangkan:

"Perselisihan kepentingan menurut pasal 1 ayat (3) undang-undang Nomor 2 tahun 2004 adalah perselisihan yang timbul dalam hubungan kerja karena tidak adanya persesuaian paham mengenai perusahan 
syarat-syarat kerja sebagaimana ditetapkan dalam perjanjian kerja, peraturan perushaan dan kesepakatan kerja Bersama" 15

Perselisihan hak dan perselisihan kepentingan yang terjadi pada hasil analisis data dinas ketenagakerjaan kota tangerang pada bulan januari sampai bulan Desember 2017 terdapat 22 kasus perselisihan hak dan 30 kasus perselisihan kepentingan. Dari hasil wawacara terdapat risalah perundingan antara serikat pekerja dengan perusahaan banyak mengalami jalan butu dalam penyelesaian bipartite.

Kasus yang timbul di dalam perusahaan yakni timbulnya perselisihan hubungan industrial secara garis besarnya adalah sebagai berikut:

a. Tidak dilaksanakannya hak pekerja

Hak pekerja secara normative yang sudah ditetapkan dalam perjanjian kerja, perusahaan dan kesepakatan kerja Bersama sering dilanggar oleh perusahaan. Hak merupakan segala sesuatu yang pekerja tuntut kepada perusahaan. Hak pekerja tersebut sering dilanggar oleh perusahaan karena peran seringkat pekerja dalam memperjuangkan hak anggota serta kemampuan aspek pembelaan yang lemah dalam memperbaharui kondisi hubungan kerja.

b. Kesadaran pekerja akan kesejahteraan

Tujuan hokum ketenagakerjaan adalah memberikan keadilan social bagi pekerja dan keluarganya. Pekerja melakukan pekerjaan untuk mendapatkan kehidupan yang sejahtera, sering terjadi perselisihan penyesuaian kenaikan upah, bonus, tunjangan hari raya, tunjangan upah lembur dan lainya. Pihak perusahaan akan selalu menunda kesejahteraan pekerja dengan alasan efisiensi, efektivitas dan produktivitas. Kebijaksanaan pengumpahan sebagaimana diatur dalam pasal 88 undangundang nomor 13 tahun 2003 ayat (2) meliputi:

1) Upah minuman

2) Upah kerja lembur

3) Upah tidak masuk karna berhalangan

4) Upah tidak masuk kerja karena melakukan kegitan diluar pekerjaannya.

5) Upah karena menjalakan hak istirahat kerjanya

6) Bentuk dan cara pembayaran upah

7) Denda dan potongan upah

8) Hal yang diperhitungkan dengan upah

9) Struktur pengupahan yang proposional

10) Upah untuk pembayaran pesangon

11) Upah untuk pajak penghasilan 
c. Aksi mogok pekerja dalam perusahaan

Mogok kerja menurut pasal 1 angka 23 undang-undang nomor 13 tahun 2003 tentang ketenagakerjaan dimaksudkan sebagai tindakan pekerja yang direncanakan dan dilaksanakan secara Bersama-sama dan atau oleh serikat pekerja untuk menghentikan atau memperlambat pekerjaan.

Penyelesaiann bipartite di dalam perusahaan banyak mengalami kedala pada factor kurangnya komunikasi antara serikat pekerja dengan perusahaan. Pekerja dan serikat pekerja mengalami jalan butu dalam perundingan dan melakuaan aksi ade kekuatan dengan demo dalam perusahaan dengan memaksa menghentikan kegiatan produksi. Akasi demo pekerja sering diagendakan pada setiap hari buruh pada tanggal 1 mei dengan tuntunan upah yang layak, hapus kerja kontrak (outsourcrhing) dan hapus peraturan Menteri tenaga kerja nomor 78 tahun 2017 tentang perusahaan

\section{d. Pemutusan Kerja oleh Perusahaan}

Pemutusan hubungan kerja oleh perusahaan merupakan awal petaka pekerja karena kehilangan mata pencaharian hidup dengan keluarganya. Pemutusan hubungan kerja oleh pihak perusahaan tanpa meminta perundingan dan persetujuan terlebih dahulu dari pihak serikat pekerja. Penyellesaian secara bipartite antara pihak perusahaan dengan serikat pekerja, dimana pihak pekerja dalam pihak yang lemah dari aspek sosial ekonomis kurang mendapatkan pembelaan dan perlindungan hukum. Pihak perusahaan melakukan penekanan terhadap pihak pekerja atau serikat pekerja dengan merumahkan pekerja dalam batas waktu yang tidak ditentukan. Perusahaan melakukan pemutusan hubungan kerja mengupayakan tanpa pemberian uang pesangon, uang jasa atau uang penghargaan masa kerja berdasarkan Pasal 157 Undang-Undang Nomor 13 Tahun 2003 Tentang Ketenagakerjaan.

e. Jenis pelanggaran yang dilakukan oleh pekerjaan

Pekerja dalam melaksanakan hubungan kerja, terkena pelanggaran terhadap disiplin kerja. Banyak pekerja yang sering melakukan mangkir dalam 5(lima) hari berturut-turut tanpa keterangan, dikatagorikan mengundurkan diri secara sepihak,pekerja melakukan kesalahan dalam bekerja sehingga merugikan perusahaan, dan lainnya perbuatan pelanggaran hukum perdata menurut pasal 1365 KHUHPerdata disebut "onrechtmatige daad" diberikan surat peringatan 1,2 dan 3 dan scorsing 
serta penundaan kenaikan jabatan dan tunjangan. Adapun pelanggaran hukum pidana berupa kejahatan pihak perusahaan melaporkan kepada penyidik darikepolisian pihak serikat pekerja melakukan pembelaan hubungan industrial yang banyak dipengaruhi oleh pihak perushaan sehingga sanksi hukuman lebih diskriminasi atas berbagai hubungan primordial dan SARA (suku, ras, dan agama). Serta rencana perusahaan untuk mengurangi jumlah pekerja tetap dan mengganti dengan pekerja kontrak.

Peran penguasaha dan seringkat pekerja dalam penyelesaian bipartite di dalam perusahaan diperlukan Lembaga kerja sama yang memahami implemnetasi Undang-Undang Nomor 13 tahun 2003 tentang penyelesaian perselisihan hubungan industrial mengenai hal sebagai berikut :

a) Perbedaan mengenai keadaan ketenagakerjaan di dalam perusahaan yang transparan dalam perusahan perjanjian kerja. Peraturan perusahan dan peran seringkat pekerja dalam merumuskan kesepakatan kerja Bersama dalam mencapai tujuan keadilan social bagi kehidupan pekerja dan keluarganya.

b) Hubungan kerja yang dilandasi oleh hekaket pekerja dan pengusaha dalam hubungan sosial ekonomis dan yuridis.

c) Ketidak patuhan pengusaha dan pekerja atau seringkat pekerja dalam melaksanakan isi perjanjian kerja, peraturan perusahaan dan kesempakantan kerja Bersama dalam hubungan industrial.

2. Upaya dilakukan oleh dinas ketenagakerjaan kota tangerang terhadap efektifitas Undang-Undang Nomor 13 tahun 2003 dalam penyelesaian Mediasi dan pengadilan Hubungan Industrial

Bahwa keberadaan Dinas ketenagakerjaan didaerah kabupaten dan kota dalam melaksanakan tugasnya yaitu menyelesaikan sengketa peselisian hubungan industrial yang kenal saat ini dengan istilah penyelesaian perselisihan hubungan industrial dengan mediasi, merupakan madatori UUD 1945 dan Pancasila, UU No 13 tahun 2003 dan UU No 2 tahun 2004. Apabila penyelesaian tersebut dilakukan di pusat, maka berada dibawah Menteri ketenagakerjaan. Hal ini sesuai dengan pasal 1 angka 16 UU No 13 tahun 2003 selanjutnya menurut UU No 2 tahun 2004 tentang penyelesaian perselisihan hubungan industrial (UUPPHI) pasal 8 menyatakan:

"mediator merupakan pihak ketiga sebagai pihak menengah, yang yang harus bersifat netral dalam menyelesaikan perselisihan". 
Edisi XIX Volume 1, Januari - Juni 2019

Jurnal Penelitian dan Karya Ilmiah

Selanjutnya dalam pasal 9 diatur pula tentang syarat-syarat menjadi medial yang ditidak lanjuti dalam kepmen tenaga kerja No./kep/42/VI/2004 tentang pengangkatan mediator serta tata kerja mediator.

Mediator sebagai pengawai negri sipil (PNS) tentu mempunyai atasan. Selanjutnya dikarenakan bahwa UU No.2 tahun 2004 yang mengatur mediator kelihatanya kabur, distriminatif, karena tidak ada keetentuan yang memperbolehkan mediator lain selain PNS bidang ketenagaankerja.

\section{Penutup}

Perselisihan hubungan industrial tidak mengacu kepada UndangUndang Nomor 13 Tahun 2003 Tentang Ketenagakerjaan Jo UndangUndang Nomor 2 Tahun 2004 Tentang Penyelesaian Perselisihan Hubungan Industrial. Mogok kerja dan unjuk rasa pada setiap hari buruh Nasional tanggal 1 Mei disebut Mayday, merupakan penolakan terhadap hak pekerja oleh serikat pekerja akibat ketidak adilan berupa kesejahteraan hdup pekerja dan keluarganya.

Sudah selayaknya kebijakan pemerintah memberikan perlidungan kepada pekerja yang mempunyai kedudukan yang lemah secara social dan ekonomi terhadap pihak perusahaan.

Bentuk penyelesaian perselisihan menurut Undang-Undang Nomor 2 Tahun 2004 tidak dilaksanakan secara Bipartite dan Tripartite oleh pengusaha dan pemerintah , sehingga aspek penegakan hukum ketenagakerjaan selalu diselesaikan dengan adu kekuatan antara pengusaha,pemerintah dan serikat pekerja.

Hukum ketenagakerjaan secara esensial mengatur secara normative melalui upaya mediasi, arbitrasi bahkan Pengadilan Industial oleh pihak perusahaan dan pihak pemerintah sebagai sarana penyelesaian perselisihan hubungan industrial. Namun upaya tersebut tidak dilakukan oleh perusahaan agar buruh tidak dapat menuntut haknya dalam tuntutan upah minimum,pekerja kontrak,pemutusan hubungan kerja sepihak sebagai pangkal persoalan yang tidak pernah dituntaskan di negara Indonesia yang berkeadilan social berdasarkan sila ke lima dari Pancasila sebagai ideologi negara.

Perselisihan hubungan industrial seharusnya diputuskan oleh pemerintah sebagai pihak penguasa dalam melaksanakan keadilan sosial bagi pekerja dan keluarganya. Oleh karena itu pemerintah wajib untuk melaksanakan peraturan perUndang-Undangan dibidang ketenaga kerjaan 
yaitu Undang-Undang Nomor 13 Tahun 2003 tentang ketenagakerjaan dan Undang-Undang Nomor 2 tahun 2004 tentang penyelesaian perselisihan hubungan industrial.

\section{Referensi}

Khakim, A. (2003). Pengantar Hukum Ketenagakerjaan. Citra Aditya Bakti: Bandung.

Libertus, J. (2006). Hak-Hak Pekerja Bila di PHK.Visi Media: Tangerang. Shamad, Y. (1995). Hubungan Industrial di Indonesia. Bina Sumber Daya Manusia: Jakarta.

Undang-Undang Nomor 13 Tahun 2003 Tentang Ketenagakerjaan.

Undang-Undang Nomor 2 Tahun 2004 Tentang Penyelesaian Perselisihan Hubungan Industrial. 